\title{
Efficiency of Sanitary Treatment in Poultry Breeding and Poultry Meat Processing Plant
}

\author{
A. KAŠKOVÁ ${ }^{1}$, O. ONDRAŠOVIČOVÁ ${ }^{1}$, J. SOKOL ${ }^{2}$, M. VARGOVÁ ${ }^{1}$, \\ S. ŠMIRJÁKOVÁ ${ }^{1}$, M. ONDRAŠOVIČ ${ }^{1}$, M. CHOVANEC ${ }^{3}$ \\ ${ }^{1}$ Department of the Environment, University of Veterinary Medicine, Košice, Slovak Republic \\ ${ }^{2}$ Regional Veterinary and Food Administration, Trnava, Slovak Republic \\ ${ }^{3}$ Slovak Agricultural University, Nitra, Slovak Republic \\ Received September 11, 2005 \\ Accepted June 30, 2006
}

\begin{abstract}
Kašková A., O. Ondrašovičová, J. Sokol, M. Vargová, S. Šmirjáková, M. Ondrašovič, M. Chovanec: Efficiency of Sanitary Treatment in Poultry Breeding and Poultry Meat Processing Plant. Acta Vet. Brno 75, 2006: 611-617.

The aim of this study was to observe the effectiveness of disinfection on a broiler farm and in a plant processing the poultry from this farm. The broiler farm was disinfected with a preparation based on peracetic acid while a preparation based on quarternary ammonium salt was used in the processing plant. We evaluated swabs taken from surfaces, which come into contact with broilers and broiler meat. Results of the swabs taken by standard microbiological swabbing method were evaluated with results of the swabs taken by the ATP-bioluminescence method. The microbiological examination included total counts of microorganisms, coliform count and moulds. When using the standard plate counts method on the broiler farm we found that the plate counts in $0 \%$ of swabs were $<1$, in $12 \%$ of swabs ranged between $1-100$ CFU while in $88 \%$ of swabs reached $>100 \mathrm{CFU}$. In the processing plant, out of $22 \%$ of swabs $<1 \mathrm{CFU}$ were recovered, in $36 \%$ of swabs plate counts ranged between $1-100 \mathrm{CFU}$ and in $42 \%$ of swabs plate counts reached $>100$. The bioluminescence method was applied only in the processing plant where $<100,100-300$ and $>$ 300 RLU were measured in 80,10 and $10 \%$ of swabs, resp. Our observations and results allowed us to conclude that the disinfectants tested appeared suitable for the respective premises and the ATP bioluminescence method could be use as a as a suitable complement for detection of cleanliness of individual surfaces.
\end{abstract}

Sanitization, disinfection, poultry, processing plant, standard plate counts

The present requirements on the production of high-quality and safe food are a subject of concern of professionals and wide consumer public in advanced countries with terminal impact on economics of agricultural production, particularly the primary production. According to the valid standards in the Slovak Republic, and in the interest of protection of consumer's health and WHO and FAO recommendations, food producers are bound to make steps which eventually prevent the risk associated with consumption of their products (Hofmann 2000; Burdová et al. 2001). As a result, all production stages must comply with the rules of correct operation practice and the HACCP system must be introduced gradually as an extension of correct operation practice. Sanitation processes are an inevitable part of food production as they influence hygiene and outcome of the entire production system (Bremner and Johnston 1996).

Poultry industry is one of the most hygiene-conscious sectors of livestock breeding. The cleaning and disinfection in large plants is ensured by specialized sanitation teams.

Monitoring of hygiene under operating conditions is ensured by traditional microbiological swabs and lately also by the ATP-detecting bioluminescence method capable of providing information about contamination of surfaces in less than 10 minutes (Green et al. 1999).

Address for correspondence:

Andrea Kašková

Department of the Environment

University of Veterinary Medicine

Komenského 73,041 81 Košice, Slovak Republic
Phone: +421905982068

E-mail: ajka77@yahoo.com kaskova@uvm.sk

http://www.vfu.cz/acta-vet/actavet.htm 
The present study focused on the evaluation of disinfection with peracetic acid-based disinfectant and quarternary ammonium compound on a poultry farm with broilers housed on deep litter and in a poultry processing plant slaughtering and processing broilers from the investigated farm. Potential transfer of contamination from the farm to the processing plant was also investigated. Bacterial plate counts were determined on the farm and in the plant after cleaning (before disinfection), after disinfection, and during the operation. It is clear that cleaning and disinfection are processes essential for good functioning of the food processing plant and production of hygienic and safe food.

\section{Materials and Methods}

The study was divided into two parts, laboratory and field ones. The laboratory investigations focused on testing of bactericidal effectiveness of disinfectants on a broiler farm and in the processing plant. The activity of disinfectants was tested by a suspension test after 5, 20 and 60 minutes. Investigations on the broiler farm which housed 10000 broilers and in the broiler processing plant consisted of taking bacteriological swabs during production and determining plate counts of investigated micro-organisms by the standard plate method. ATPbioluminescence method was used in the processing plant to check the cleanliness of surfaces.

Testing the disinfection efficiency by the qualitative suspension test under laboratory conditions

Tests were carried out with peracetic acid and Topax-91 disinfectant based on a quarternary ammonium compound. Bactericidal activity of disinfectants was evaluated under laboratory conditions by the method of qualitative suspension assay (AOAC 1984). Known quantities of bacterial suspension were added to a disinfectant solution of known concentration and incubated for a specified time (5, 20 and 60 minutes). Using a bacteriological loop, mixture aliquots were transferred to tubes with broth and incubated according to the requirements of respective bacteria. The tests were performed using standard collection bacteria with $E$. coli and $S$. aureus representing Gram-negative and Gram-positive bacteria, resp., B. cereus as a representative of spore-forming bacteria and A. niger as a representative of moulds.

Contact swabbing places

Selection of surfaces for swab evaluation depended on the type of operation and on the locations, which might appear critical for production. On the poultry farm, the floor, walls, ceiling, drinkers and ventilation fans were considered critical. In the processing plant, we focused on the shackling hooks, eviscerator, cooling tank, shoots, saws, boards, injector, conveyer belts and other equipment that was cleaned manually. To be able to compare the methods, swabs were taken from respective surfaces: from $100 \mathrm{~cm}^{2}$ in the processing plant and from $10-\mathrm{cm}^{2}$ areas on the farm with recalculation per $100 \mathrm{~cm}^{2}$. Five swabs were taken from respective locations. In the processing plant, swabs were taken during the production in the presence of workers and 2 - 5 hours after disinfection. On the broiler farm, swabs were taken also after emptying the houses before mechanical cleaning and after mechanical cleaning before disinfection.

Microbiological swabbing methods

Sterile cotton swabs were moistened with $10.0 \mathrm{ml}$ sterile saline in a tube. Swabbed places were marked and described. After swabbing, the cotton swab was returned back to the tube while breaking off and removing the handled part of the swab stick. The tubes with swabs were refrigerated until processing. Plate counts of total microorganisms, coliforms and moulds were determined. The samples were processed within 24 hours according to the respective standard methods (ŠVPS SR No.7089 2002). All counts were expressed as colony forming units $(\mathrm{CFU})$ for the swabbed surface (CFU per milliliter of swabbing solution $\times 10)$.

\section{ATP bioluminescence method}

The ATP-bioluminescence is based on ATP detection and quantification using an enzyme luciferase and a luciferin cofactor. Hydrolysis of ATP by luciferase produces yellow-green luminescence measured by a luminometer and converted to RLU (relative light units). As one molecule of ATP produces one photon of light, light intensity of the reaction is relative to ATP quantity in the sample (Green et al. 1999). HY-LiTE Merck system was used.

\section{Results and Discussion}

Microbial contamination of the poultry meat and its control are important for two reasons. The first reason is that poultry is an important reservoir of pathogens, such as Salmonella and Campylobacter, and a frequent source of food-borne diseases. The second reason is the inclination of raw meat to microbial spoilage if it is stored unfrozen. Some microbial contamination is inevitable due to the poultry meat character and the way it was obtained, however, it is essential to reduce it by effective control of hygiene during the respective operations (Bremner and Johnston 1996). One part of the problem is that poultry is 
transported to a slaughterhouse from various farms and is strongly contaminated by a wide spectrum of microorganisms. Most of them are eliminated during processing, but many withstand the process and may spread and cross-contaminate other carcasses. It is therefore necessary to ensure optimum hygiene conditions during processing by using detergents and disinfectants and easy-care surfaces.

After cleaning, disinfection plays a key role in the subsequent reduction of viable microorganisms. However, disinfectants used in food industry may contaminate the products and because of that the selection of disinfectants that are effective, suitable for that particular environment, non-toxic and non-tainting is of utmost importance (Holah 1995).

Sanitation is one of the most important measures in the meat industry and involves technologies not less detailed than slaughter or butcher fitting (Gracey and Collins 1992). Incipient foulness in meat and fleshy products processing are mostly composed of proteins and fats. Their composition makes an ideal matrix for multiplication of different species of microorganisms including pathogens (Hofmann 2000). Disinfection in food processing plants should remove or devitalize all disease-producing germs and reduce the counts of other germs to a level, which has no negative influence on the products.

Sanitizing agents, active against free microorganisms, may lose their activity towards germs enclosed in a biofilm. This is prevented by thorough cleaning, application of combined agents (oxidizing substances and surface-active compounds) and frequent monitoring of the surfaces. Pokludová and Šk kalou d (2002) mentioned that Listeria spp., enclosed in a biofilm, might present a problem as they are preserved well on stainless steel surfaces and survive freezing and drying.

Many authors mentioned that successfulness of antimicrobials depends on their ability to inactivate and eliminate organisms in the biofilm. Mittelmann (1998) reported that low concentrations of natrium hypochlorite at a concentration interval from 0.05 to $5 \mathrm{mg} \cdot \mathrm{l}^{-1}$ act only as inhibitors on the biofilm retained on stainless steel and only concentrations above $50 \mathrm{mg} \cdot \mathrm{l}^{-1}$ are able to inactivate the biofilm micro-organisms under controlled conditions. According to Jessen and Lammert (2003), disinfectants based on hydrogen peroxide and peracetic acid are more effective than chlorine disinfectants. Our tests showed that peracetic acid is a highly effective disinfectant already at low concentrations. The suspension test performed under laboratory conditions (Fig.1) revealed good effectiveness of this disinfectant against $E$. coli, $S$. aureus and B. cereus already at a concentration of $0.1 \mathrm{ml} \cdot \mathrm{l}^{-1}$ at 20 minutes exposure. It was also effective against moulds represented by $A$. niger, which often raise problems on poultry breeding farms, even with lethal results, at the same concentration as above but with 60 minutes exposure time. Moreover, the residual concentrations are eliminated easily by simple aeration and the compound is also environmentally friendly, as it leaves no residues.

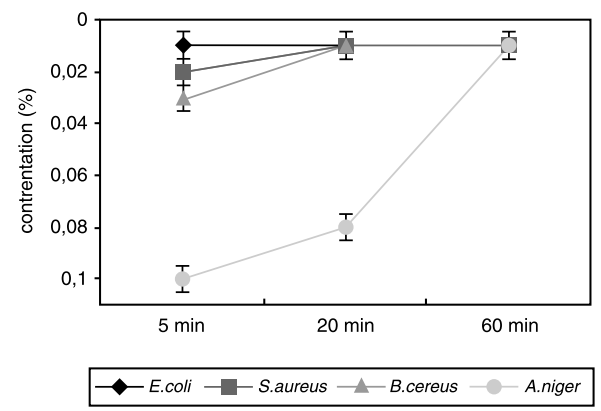

Fig. 1. Effectiveness of peracetic acid against representatives of Gram-negative, Gram-positive and spore-forming bacteria and moulds in laboratory suspension tests. Relationship between disinfectant concentration and the exposure time is shown. 
Table 1. Comparison of cleanliness of poultry farm surfaces after emptying the halls at the end of fattening (before mechanical cleaning) and after mechanical cleaning with water under pressure (before disinfection)

\begin{tabular}{|l|c|c|c|c|c|c|}
\hline & \multicolumn{3}{|c|}{ After removal of chickens } & \multicolumn{3}{c|}{ After mechanical cleaning } \\
\hline Swabbed place & TCM & Coliforms & Moulds & TCM & Coliforms & Moulds \\
\hline & \multicolumn{7}{|c|}{ CFU } & 565000 & 35000 & 704000 \\
\hline Floor & 4136000 & 345000 & 3822000 & 400 & 565000 \\
\hline Walls & 1764000 & 29000 & 2545000 & 316000 & 4000 & 530000 \\
\hline Ceiling & 1432000 & 32000 & 1288000 & 350000 & 12000 & 173000 \\
\hline Drinkers & 1870000 & 92000 & 720000 & 175000 & 11000 & 419000 \\
\hline Ventilating fans & 915000 & 75000 & 954000 & 135000 & 10000 & \\
\hline
\end{tabular}

Results are means of 5 swabs taken at individual sites from $100 \mathrm{~cm}^{2}$ surface. Altogether 50 swabs were taken.

Table 2. Mean total counts of microorganisms, coliforms and moulds after spray disinfection with peracetic acid (poultry farm)

\begin{tabular}{|l|c|c|c|}
\hline & \multicolumn{3}{|c|}{ After disinfection } \\
\hline Swabbed place & TCM & Coliforms & Moulds \\
\hline & \multicolumn{3}{|c|}{ CFU } \\
\hline Floor & 586 & 0 & 180 \\
\hline Walls & 147 & 0 & 197 \\
\hline Ceiling & 100 & 0 & 200 \\
\hline Drinkers & 190 & 0 & 160 \\
\hline Ventilating fans & 200 & 0 & 200 \\
\hline
\end{tabular}

Concentration of peracetic acid was $4 \mathrm{ml} \cdot \mathrm{l}^{-1}$ at ambient temperature of $18^{\circ} \mathrm{C}$. Results are means of 5 swabs taken at individual sites from $100 \mathrm{~cm}^{2}$ surface. Altogether 25 swabs were taken.

When tested on the broiler farm, peracetic acid appeared very effective as the cleaning process decreased plate counts of micro-organisms by $84 \%$ on average (Table 1) but disinfection ensured $99.9 \%$ effectiveness (Table 2) compared to the original state after emptying the halls. The Topax-91 disinfectant, based on quarternary ammonium compounds, showed very good efficacy. Fig. 2 shows that in the laboratory tests Topax-91

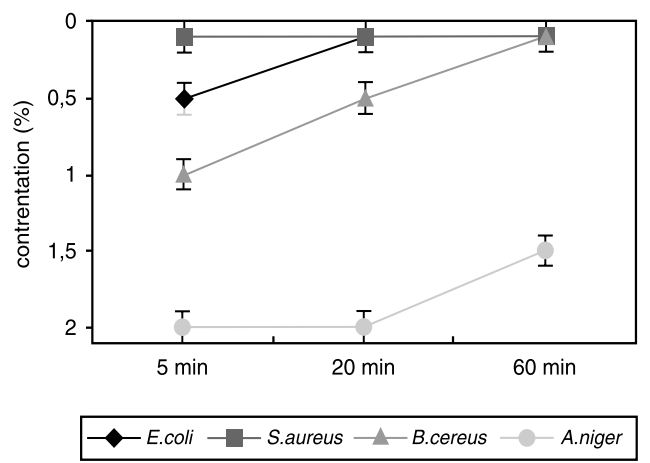

Fig. 2. Effectiveness of the disinfectant based on quarternary ammonium compound against representatives of Gramnegative, Gram-positive and spore-forming bacteria and moulds in laboratory suspension tests. Relationship between disinfectant concentration and the exposure time is shown. 
was effective against E. coli, S. aureus and B. cereus germs already at a concentration of $1 \mathrm{ml} \cdot \mathrm{l}^{-1}$ after 60 minutes of exposure and to A. niger at aconcentration of $15 \mathrm{ml} \cdot \mathrm{l}^{-1}$ after 60 minutes of exposure. According to producer's instruction Topax-91 should be used in 5 - 10 $\mathrm{ml} \cdot \mathrm{l}^{-1}$ concentration at $50{ }^{\circ} \mathrm{C}$ and exposure time 1 hour. It is therefore suitable for regular disinfection in poultry industry as it was confirmed by the results obtained after disinfection in the processing plant (Table 3 ). The only place that allowed us to recover a higher number of microorganisms after disinfection were the shackling hooks. This problem was noted in the majority of cases because, due to their shape, the cleaning and disinfection of these hooks is very difficult. To reach better results it is necessary to perform very thorough mechanical cleaning of hooks before disinfection. In the poultry processing plant, swabs were taken and evaluated also by the ATP-bioluminescence method. The results of this method correlated with those obtained by the standard plating method (Table 3). Comparison of the results of TCM and RLU is presented in Table 4.

Table 3. Mean total counts of microorganisms, coliforms and moulds after spray disinfection with a disinfectant based on quaternary ammonium compounds (processing plant)

\begin{tabular}{|c|c|c|c|c|c|c|c|c|}
\hline \multirow[b]{2}{*}{ Swabbed place } & \multicolumn{3}{|c|}{ During the production } & \multirow{3}{*}{$\begin{array}{l}\text { ATP } \\
\text { RLU }\end{array}$} & \multicolumn{3}{|c|}{ After disinfection } & \multirow{3}{*}{$\begin{array}{l}\text { ATP } \\
\text { RLU }\end{array}$} \\
\hline & TCM & Coliforms & Moulds & & TCM & Coliforms & Moulds & \\
\hline & \multicolumn{3}{|c|}{$\longrightarrow \mathrm{CFU} \longrightarrow$} & & \multicolumn{3}{|c|}{$-\mathrm{CFU} \longrightarrow$} & \\
\hline Shackling hooks & 1560000 & 240000 & 720000 & 42000 & 11000 & 70 & 450 & 770 \\
\hline Eviscerator & 470000 & 13800 & 280000 & 36000 & 1500 & 0 & 240 & 48 \\
\hline Cooling tank & 1800 & 5100 & 1200 & 2700 & 10 & 0 & 100 & 11 \\
\hline Shoots & 7600 & 1300 & 2800 & 850 & 20 & 0 & 70 & 28 \\
\hline Conveyer belts & 2300 & 700 & 1400 & 870 & 10 & 0 & 70 & 24 \\
\hline Saws & 5200 & 700 & 1200 & 720 & 120 & 0 & 110 & 120 \\
\hline Boards & 8700 & 3200 & 2400 & 940 & 150 & 0 & 180 & 130 \\
\hline Plastic boards & 6500 & 1200 & 700 & 320 & 50 & 0 & 60 & 220 \\
\hline Knife & 4400 & 1600 & 2500 & 530 & 0 & 0 & 0 & 5 \\
\hline Injector & 75000 & 4500 & 53200 & 1600 & 430 & 0 & 380 & 460 \\
\hline
\end{tabular}

Concentration of QAC was $5 \mathrm{ml} \cdot \mathrm{l}^{-1}$ at $50^{\circ} \mathrm{C}$. Results are means of 5 swabs taken from $100 \mathrm{~cm}^{2}$ surface at all sites. Altogether 100 swabs were taken. The results obtained by the standard microbiological method are compared with the results of ATP-bioluminescence method.

Table 4. Percentage comparison of disinfectant efficiency in the poultry meat processing plant

\begin{tabular}{|c|c|c|c|}
\hline TCM(CFU) & $<1$ & $1-100$ & $>100$ \\
\hline ATP(RLU) & $(11$ sites $)$ & $(18$ sites $)$ & $(21$ sites $)$ \\
\hline$<100$ & 22 & 32 & 26 \\
\hline $100-300$ & 0 & 4 & 6 \\
\hline$>300$ & 0 & 0 & 10 \\
\hline
\end{tabular}

Results are expressed in \%. TCM determined by standard plate count method. RLU determined by the ATPbioluminescence method. Swabs were taken from 50 sites.

A number of studies were published on the reliability of the two methods. Poulis et al. (1993) performed tests in food processing plants and found poor relationship between ATPbioluminescence and the contact method. However, either method in its own right is useful to check the cleanliness in food processing plants. ATP measurement has a great advantage, because it is quick and easy. Tebbutt (1991) compared the contact agar method and swabbing method in the inspection of surface cleanliness in food processing before and after cleaning. He obtained better results with plates, which were as sensitive as the swabbing method. 
Application of sanitizers after cleaning can often interfere with the surface of bacteria, so the plate method gives negative results or low counts. However, it is a fact that a fine film or even a food layer may remain on the surface and is not detected by the traditional method. This is the biggest danger associated with plate techniques. Residues from processing, such as blood and tissues, remain on the equipment and can participate in increasing the RLU values because the enzyme luciferase reacts with both eukaryotic and prokaryotic ATP. These residues indicate inadequate sanitation and can be detected by the ATP method, whereas plate methods are useful only for quantification of counts of microorganisms left on the equipment (Green et al. 1999). If the surfaces of processing equipment show higher values of ATP regardless of their source, these surfaces should be cleaned repeatedly before the processing operations can start.

Moore and Griffith (2002) studied the dependence between the surface quality, cleaning and disinfection and the testing methods. The number of surfaces considered suitable for food production increased after cleaning but the agreement between the testing methods varied with regard to the type of processed food. Insufficient detection of proteins was most frequently observed on surfaces in bakeries while ATP-bioluminescence and the standard microbiological methods failed mostly in freezing facilities and cheese processing plants. The authors concluded that it is necessary to combine these methods when monitoring cleanliness in these facilities. Oulahal-Lagsir et al. (2000) accept the use of ATP-bioluminescence method for quantification of biofilm removal. In comparison with the swabbing method, their results differed by $42 \%$ on stainless steel and by $74 \%$ on polypropylene surfaces. Frank and Chie mlew ski (1997) disinfected various surfaces with quarternary ammonium compounds. They applied QAC solution of concentration $200 \mathrm{mg} \cdot 1^{-1}$. Their results showed that stainless steel and smooth polycarbonates could be disinfected easier $\left(5 \mathrm{CFU} / \mathrm{cm}^{2}\right.$ of residual germs) than surfaces of mineral resins $\left(100 \mathrm{CFU} / \mathrm{cm}^{2}\right.$ of residual germs). Sanitation with quarternary ammonium compounds performed in their study reduced population of $S$. aureus more than 1.000 -fold on all monitored surfaces except the mineral ones. In our case, disinfection with QAC at a concentration of $5 \mathrm{ml} \cdot \mathrm{l}^{-1}$ ensured $99.2 \%$ effectiveness.

In conclusion, sanitary treatment is one of the most important components of the control system HACCP. Cleaning and disinfection as a part of everyday operation practice are essential for high hygienic level in food production in the framework of legislation requirements

The farm poultry is highly contaminated with many kinds of bacteria. This has a great influence on contamination of entry parts of the processing plant. The count of microorganisms on surfaces in the processing plant varies throughout the day and depends on surface and the part of the processing stage. Our observations and results allowed us to conclude that the disinfectants tested appeared suitable for the respective premises and the ATP bioluminescence method could be use as a as a suitable complement for detection of cleanliness of individual surfaces.

If the poultry leaves the farm with contamination of about $2.10^{6} \mathrm{TCM}$ per $10 \mathrm{~cm}^{2}$, it is very important to ensure its disinfection corresponding to national and EU regulations in order to prevent an increase in the counts of microorganisms in food by faulty sanitation programme.

\section{Účinnost' sanitačného režimu vo výkrme brojlerov a v potravinárskej prevádzke spracujúcej hydinu}

Sanitačný režim je jednou z najdôležitejších súčastí kontrolného systému HACCP. Čistenie a dezinfekcia ako súčast každodennej výrobnej praxe sú nepostrádatelné pre správne fungovanie výroby potravín v rámci legislatívnych požiadaviek. Cielom práce bolo sledovanie účinnosti dezinfekcie na farme výkrmu brojlerov a v hydinárskom závode spracúvajúcom mäso 
zo sledovanej farmy. Vo výkrmni brojlerov bol na dezinfekciu použitý prípravok s obsahom kyseliny peroctovej a v spracovatelskej prevádzke komerčný prípravok na báze kvartérnej amónnej soli. Vyhodnotené boli stery z povrchov prichádzajúcich do kontaktu s brojlermi a surovinou. Výsledky sterov získané štandardnou metódou mikrobiologických sterov boli porovnané s výsledkami sterov ATP-bioluminiscenčnej metódy. Z mikrobiologických ukazovatelov boli stanovené celkové počty mikroorganizmov, počty koliformných mikroorganizmov a plesní. Pri použití štandardnej platňovej metódy, celkové počty mikroorganizmov v hale pre výkrm brojlerov po dezinfekcii sa pohybovali v rozmedziach $<1$, od 1 do 100 , a > 100 KTJ v 0, 12 a $88 \%$ sterov, a v potravinárskom podniku 22, 36 a $42 \%$ sterov. Bioluminiscenčná metóda bola použitá na hodnotenie iba v potravinárskej prevádzke a zistené hodnoty sa pohybovali v rozmedziach < 100, 100 - 300,> 300 RLU na 80,10 a $10 \%$ sterov. Na základe našich sledovaní a dosiahnutých výsledkov bolo zistené, že použité dezinfekčné prípravky boli vhodné pre dané prevádzky a ATP-bioluminiscenčná metóda je vhodným doplnkom pri detekcii čistoty jednotlivých povrchov. Avšak ani najúčinnejšie dezinfekčné prostriedky nezaručia dokonalú čistotu, ak dezinfekcii v živočíšnej výrobe nebude predchádzat' kvalitná mechanická očista a vhodný spôsob čistenia v spracovatel'ských prevádzkach.

\section{References}

ASSOCIATION OF OFFICIAL ANALYTICAL CHEMISTS 1984: Official Methods of Analysis, 14th edn. AOAC Virginia

BARBALHO TCF, ALMEIDA PF, ALMEIDA RCC, HOFER E 2005: Prevalence of Listeria spp. at a poultry processing plant in Brazil and a phage test for rapid confirmation of suspect colonies. Food Control 16: 211-216

BREMNER A, JOHNSTON M 1996: Poultry Meat Hygiene and Inspection. WB Sauders Company Ltd. The University Press, Cambridge, pp. 125-169

BURDOVÁ O, TUREK P, CABADAJ R 2001: Hygiene of milk from the point of view of correct production practice and application of the HACCP system in production and processing of milk. SVS Bratislava, pp. 47-52 (In Slovak)

FRANK JF, CHIEMLEWSKI RA 1997: Effectiveness of sanitation with quaternary ammonium compound or chlorine on stainless steel and other domestic food-preparation surfaces. J Food Protect 60: 43-47

GRACEY JF, COLLINS DS 1992: Meat Hygiene. 9th Edition, Bailliere Tindall, The Bath Press, London, pp. 122-131

GREEN TA, RUSSELL SM, FLETCHER DL 1999: Effect of chemical cleaning agents and commercial sanitizers on ATP bioluminescence measurement. J Food Protect 62: 86-90

HY-LiTE 2 System 2000: Working manual. Germany: Merck KGaA

HOFMANN I 2000: Sanitation measures and appropriate sanitation activities are of exceptional importance in meat processing. Maso 1: 19-22 (In Czech)

HOLAH JT 1995: Special needs for disinfectants in food- handling establishments. In Disinfectants: Actions and Applications. Office Internationàl Des Èpizooties. Rev Sci Tech 14: 95-104

JESSEN B, LAMMERT L 2003: Biofilm and disinfection in meat processing plants. Int Biodeterior Biodegrad 51: 265-269

METHODS OF SAMPLING AND EXAMINATION OF SWABS SVPS SR No.7089/02-250: Determination of total number of microorganisms and coliforms by the MST method (In Slovak).

MITTELMAN MW 1998: Structure and functional characteristics of bacterial biofilms in fluid processing operations. J Dairy Sci 81: 2760-2764

MOORE G, GRIFFITH C 2002: A comparison of traditional and recently developed methods for monitoring surface hygiene within the food industry: an industry trial. Int J Environ Health Res 12: 317-329

OULAHAL-LAGSIR N, MARTIAL-GROS A, BONNEAU M, BLUM LJ 2000: Ultrasonic methodology coupled to ATP bioluminescence for the non-invasive detection of fouling in food processing equipment - validation and application to a dairy factory. J Appl Microbiol 83: 433-441

POKLUDOVÁ L, ŠKALOUD J 2002: Zoonoses and disinfection in food production. Poděbrady: Př́vorovy dny. Proc. of the 5th Conference on DDD, pp. 155-168 (In Czech)

POULIS JA, DE PIJPER M, MOSSEL DA, DEKKERS PP 1993: Assessment of cleaning and disinfection in the food industry with the rapid ATP- bioluminescence technique combined with the tissue fluid contamination test and a conventional microbiological method. Int J Food Microbiol 20: 109-116

TEBBUTT GM 1991: An assessment of cleaning and sampling methods for food-contact surfaces in premises preparing and selling high-risk foods. Epidemiol Infect 106: 319-327 